\title{
Toxicological and Sensitization Studies of Novel Vascular Prostheses Made of Bacterial Nanocellulose Modified with Chitosan (MBC) for Application as the Tissue-Engineered Blood Vessels
}

\author{
Joanna Piasecka-Zelga ${ }^{1} \cdot$ Piotr Zelga $^{2}$ (D) Karolina Gronkowska ${ }^{1} \cdot$ Jakub Madalski $^{1}$ - Joanna Szulc ${ }^{1}$. \\ Justyna Wietecha ${ }^{3} \cdot$ Danuta Ciechańska $^{3} \cdot$ Radosław Dziuba $^{3}$
}

Received: 17 June 2020 / Revised: 11 January 2021 / Accepted: 25 March 2021 / Published online: 4 May 2021

(C) The Author(s) 2021

\begin{abstract}
Background Tissue-engineered blood vessels (TEBV) represent an attractive approach for overcoming reconstructive problems associated with vascular diseases in humankind by providing small caliber vascular grafts. The study evaluates biocompatibility and bioaffinity of vascular prostheses made from chitosan-modified bacterial cellulose (MBC) as potential scaffolds for TEBV. Methods During the study, acute oral toxicity, up-and-down procedure (UDP), OECD test No. 425 on 10 Imp:WIST rats, intradermal reactivity on three Imp:BN albino rabbits, and sensitization on $15 \mathrm{Imp}: \mathrm{DH}$ guinea pigs were performed. The local effects were determined 1 month after intramuscular implantation of prostheses in $30 \mathrm{Imp}:$ WIST rats. Histopathological and pathomorphological studies were conducted following complete removal of implants with peri-implant tissue.

Results There were no signs of toxicity; the median lethal oral dose (LD50) was greater than $2 \mathrm{~g} / \mathrm{kg}$ body weight for the rats. No allergic reactions were observed in the case of the guinea pig maximization test. Vascular grafts did not induce significant reactive changes in intradermal reactivity test (Main Irritation Index value 0.03 ) and do not induce inflammatory changes or hyperplasia of the muscle tissue surrounding the implant. Histopathological examination revealed ingrown vascular-connective bands.

Conclusions Tubes made of MBC offer strong potential for use in future TEBV programs for vascular surgery.

Lay Summary Currently, the number of autologous grafts for coronary artery disease and foripheral artery disease is limited. Particularly materials that will have contact with blood must comply with certain requirements such as mechanical strength, biocompatibility, and no potential to evoke adverse reactions. Bacterial nanocellulose modified with chitosan (MBC) due to its mechanical and biological properties is a promising material for replacing small-diameter vessels grafts. Although previous studies have not shown the toxicity of nanocellulose, we want to check whether medical products based on MBC will be safe when testing in vivo. Thirty Imp:WIST rats and $15 \mathrm{Imp}: \mathrm{DH}$ guinea pigs were subject of thorough analysis of potential toxicological and sensitization effect that may develop after applying vascular prostheses made from MBC to living organism. The analysis involved also histopathological and pathomorphological studies following complete removal of implants with periimplant tissue. The results show that MBC prostheses do not cause any allergic, intradermal reactions and finally, do not display acute toxicity towards the organism in which it is implanted. Moreover, they had not induced inflammatory changes or hyperplasia of the muscle tissue surrounding the implantation sites, thus showing good biocompatibility. Obtained results were discussed with other available studies investigating various aspects of bacterial cellulose or modified bacterial cellulose influence on cells and tissues in both in vitro and in vivo studies. This is the first study analyzing the toxicological and sensitization effect which MBC may evoke and confirm the strong potential for use in future TEBV programs for vascular surgery.
\end{abstract}

Joanna Piasecka-Zelga and Piotr Zelga contributed equally to this work.

Piotr Zelga

piotr_zelga@op.pl

1 Research Laboratory for Medicine and Veterinary Products in the GMP Quality System, Nofer Institute of Occupational Medicine, Św. Teresy od Dzieciątka Jezus 8, 91-348 Lodz, Poland
2 Department of General and Colorectal Surgery, Medical University of Lodz, Pl. Hallera 1, 91-647 Lodz, Poland

3 Institute of Biopolymers and Chemical Fibres, Lodz, Poland 
Keywords Modified bacterial cellulose (MBC) scaffold; Implants · Toxicity test · Contact allergy $\cdot$ Histopathology $\cdot$ In vivo · TEBV

\section{Introduction}

Bacterial cellulose (BC) represents an interesting emerging biocompatible nanomaterial which can be used in a wide range of biomedical applications, such as production of artificial blood vessels or microvessels and artificial skin [1]. Microbial cellulose is biosynthesized by the Gramnegative bacterium named Gluconacetobacter xylinus, formerly Acetobacter xylinum [2]. Bacterial cellulose is susceptible to modifications that significantly improve its properties and/or functionality. As a result, new BCbased nanocomposites are obtained, for example, $\mathrm{BC} / \mathrm{chi}$ tosan, $\mathrm{BC} /$ collagen, $\mathrm{BC} /$ gelatin, or $\mathrm{BC} /$ fibroin [1]. These nanocomposites are a combination of the good properties of BC with specific features of other materials for specific applications [3]. Chitosan modification is an example of improving the properties of bacterial cellulose. Chitosanbased biomaterials are considered antimicrobial, functional, renewable, nontoxic, biocompatible, bioabsorbable, and biodegradable biopolymer agents [4]. Many factors and qualities of chitosan derivatives make the BC/chitosan nanoparticles adequate materials for implantation. Chitosan is also characterized by good mechanical properties in wet state, high ability to maintain moisture, high bioaffinity, bacteriostatic, and bactericidal activity against bacteria Escherichia coli $\mathrm{G}(-)$ or Staphylococcus aureus $\mathrm{G}(+)$. Moreover, BC/chitosan molecules show susceptibility to specific hydrolytic enzymes, for example, lysozyme. During the enzymatic degradation of chitosan, bioactive mono- and oligosaccharides are being released, which stimulate angiogenesis and tissue regeneration [5]. These types of nanoparticles are promising to advance strategies to treat vascular disease. It has been proven that MBC provides a good scaffold for the host cells and promotes the regeneration of tissues by the body. It has been found that due to its mechanical and biological properties, bacterial cellulose modified with chitosan is a promising material for replacing small-diameter vessels grafts. In recent years, bioengineering of artificial blood vessels is focused mainly on discovery and development of new artificial vascular substitutes, alternative materials that integrate with the patient's native tissue to restore physiological function [6]. The main challenge for tissue engineering is to develop new biologically active small-diameter grafts. Currently expanded-polytetrafluoroethylene (ePTFE; synthetic fluorocarbon polymer), polyethylene terephthalate (Dacron; polymer containing ester functional group), and polyurethanes (formed through a reaction between isocyanates and polyol) are the most commonly used synthetic graft materials for artificial blood vessels [6]. However, these commercial prosthesis-materials are unsuitable for microsurgical requirements, because they have larger diameter than $3 \mathrm{~mm}$. Therefore, they cannot be used in microvessels surgeries. Tissue-engineered blood vessels (TEBVs) represent an innovative approach for overcoming reconstructive problems associated with vascular diseases by providing small-caliber vascular grafts. Moreover they confirm that $\mathrm{BC}$ has high mechanical strength, promotes in situ vascular tissue regeneration, can be shaped into three-dimensional structures, and does not require pre-treatment in the form of cell seeding. The ideal vascular prosthesis should be resistant to thrombosis, inflammation, and excessive thickening of the intima. Numerous publications suggest that BC seems to be the best candidate among those possible to construct novel vascular prosthesis and substitutes of small blood vessels [7, 8].

In this study, a novel vascular prostheses made of bacterial nanocellulose modified with chitosan (MBC) will be tested for their potential toxicity and adverse sensitization effects. The toxicology study of nanocellulose and nanocellulosebased biocomposites is still restricted at a very preliminary stage (mainly on the level of cytotoxicity) [9]. Although previous studies have not shown the toxicity of nanocellulose, we want to check in vivo whether our product will be safe for patients in the future. Long-term stability and suitability to replace small-caliber blood vessels without significant thrombogenicity must be investigated. Study of compliance between the graft and the surrounding native vessels and tissues, together with the postoperative complications, is now warranted and is the subject of current study.

\section{Experimental Section-Materials}

\section{In Vitro Testing}

The assessment of cytotoxic activity in vitro was conducted in the Cell Culture Laboratory, Department of Histology and Embryology of the Wrocław Medical University. The study was conducted on a reference cell line, mouse fibroblasts 3T3/ Balb obtained from the Tissue Bank, Institute of Immunology and Experimental Therapy of the Polish Academy of Sciences in Wrocław. The cells were stored in liquid nitrogen, with the addition of about $10 \%$ DMSO. After thawing, the cells were passed through twice with a solution of $0.05 \%$ trypsin + $0.02 \%$ EDTA in PBS, pH 7.2 (provided by SIGMA, USA).

The following composition was used for fibroblast cell culture: MEM Eagle (SIGMA, USA); 10 \% FCS (SIGMA, 
USA); glutamine, $1 \mathrm{mM} / \mathrm{ml}$ (SIGMA, USA); penicillin, 100 $\mu \mathrm{g} / \mathrm{ml}$; streptomycin, $100 \mu \mathrm{g} / \mathrm{ml}$.

The cells were cultured under the conditions recommended for tissue culture in an atmosphere of $5 \% \mathrm{CO} 2$, at $37^{\circ} \mathrm{C}$, with constant chamber moisturization.

\section{In vivo Testing}

The present study was conducted in accordance with the prior consent of the No. 9 Local Ethics Committee for animal experiments in Lodz and the Ethics Committee of the Medical University of Lodz, Poland; Resolution No. 49/LB 483/2009 on September 21, 2009. The work was supported by Development of Biological Vascular Prostheses of Modified Bacterial Cellulose Research Project grant (no. N205 068 31/ 3102); patent PL 190961 "Method of obtaining modified bacterial cellulose" $[10,12,15]$.

\section{Animals}

Forty rats (outbred stock Han Wistar Imp:WIST rats)healthy, both sexes, aged approximately 2 to 3 months, body mass about $300 \mathrm{~g}$

Three New Zealand albino rabbits (outbred stock Imp:BN) - healthy, both sexes, approximately 3 months old, body mass $240-350 \mathrm{~g}$

Fifteen guinea pigs (outbred stock Dunkin-Hartley Imp:D$\mathrm{H}$ ) - healthy, both sexes, aged approximately 2 to 3 months, body mass $240-350 \mathrm{~g}$

All laboratory animals were provided by the Institute of Occupational Medicine, where they were bred. The animals were housed as one animal per cage at $19-21.5^{\circ} \mathrm{C}, 55-60 \%$ relative humidity, and $/ 12 \mathrm{~h}: 12 \mathrm{~h} /$ light/dark cycle. Animals had access to standard feed and water ad libitum.

\section{Reagents}

For the sensitization test Freund's adjuvant, sodium dodecyl sulfate and cottonseed oil were supplied by Sigma-Aldrich Corporation (Poznan, Poland), while saline solution (0.9\% $\mathrm{NaCl}$ ) was provided by Baxter Manufacturing Sp. z o.o. (Lublin, Poland).

For the sensitization, aqua pro injection was provided by Baxter Manufacturing Sp. z o.o. (Lublin, Poland) and sterile gauze compress 17 filiform was supplied by TZMO SA (Torun, Poland). To validate the skin sensitization assessment, $85 \% \alpha$-hexyl cinnamaldehyde was supplied by SigmaAldrich Corporation (Poznan, Poland).

\section{Tested Materials}

The research material was modified bacterial cellulose in tubular form (BCTube). Samples for the study were provided by the
Institute of Biopolymers and Chemical Fibres, Lodz, Poland. The $\mathrm{BC}$ was synthesized using an acetic strain of bacteria, Acetobacter sp. (CCM 2360), from the Czech Collection of Microorganisms, Masaryk University, Brno, Czech Republic. Bacterial cellulose was modified with chitosan at the stage of biosynthesis - by adding chitosan oligomers to the culture medium. As presented previously [5], chitosan chains are physically incorporated into the cellulose network. Modified HestrinSchramm medium was used, composed of the following (on $1000 \mathrm{~cm} 3$ ): glucose $20.0 \mathrm{~g}$, yeast extract $5.0 \mathrm{~g}$, soy peptone 5.0 g. disodium phosphate $2.7 \mathrm{~g}$, acetic acid $1.2 \mathrm{~g}$, ethanol $20.0 \mathrm{~cm} 3$, and chitosan oligomers (ChitoOligo-100, Aminogen, Korea) 2.0 g. Modificator-ChitoOligo- 100 is a water-soluble oligomer of $\beta$ 1,4-linked D-glucosamine, produced from crab chitosan by an enzymatic process using a chitosanase, developed by the Aminogen company (Korean Patent No. 0227040). Product characteristics are as follows: molecular weight $>5 \mathrm{kDa}$, degree of acetylation $92 \%$, molecular weight distribution of 1 to 1.5 , an intrinsic viscosity of 0.020 to $0.250 \mathrm{~g} / \mathrm{D}$-sec, a moisture content $>1 \%$, and an inorganic content of 0 to $1 \%$. Samples of the BC tubes were analyzed by Fourier transform infrared spectroscopy (FTIR). BC tubes were obtained by biosynthesis for 7 days at 30 ${ }^{\circ} \mathrm{C}$ in an incubator (Fig. 1.1). Bacterial cellulose in tubular form, BC Tube (Fig. 1.2), was obtained by biosynthesis in single silicone tubes. The silicone tube (internal diameter $10 \mathrm{~mm}$, wall thickness $1.4 \mathrm{~mm}$ ) was filled with HS culture medium modified with chitosan oligomers; the ends of the tube were tightly closed with plastic plugs. The external diameter of the $\mathrm{BC}$ tube depended on the internal diameter of the silicone tube. For testing biological properties, $\mathrm{BC}$ tubes with an external diameter of $10 \mathrm{~mm}$ and wall thickness of $1.7-1.8 \mathrm{~mm}$ were used (Fig. 1.3) On Fig. 2a, SEM morphology of internal wall surface of

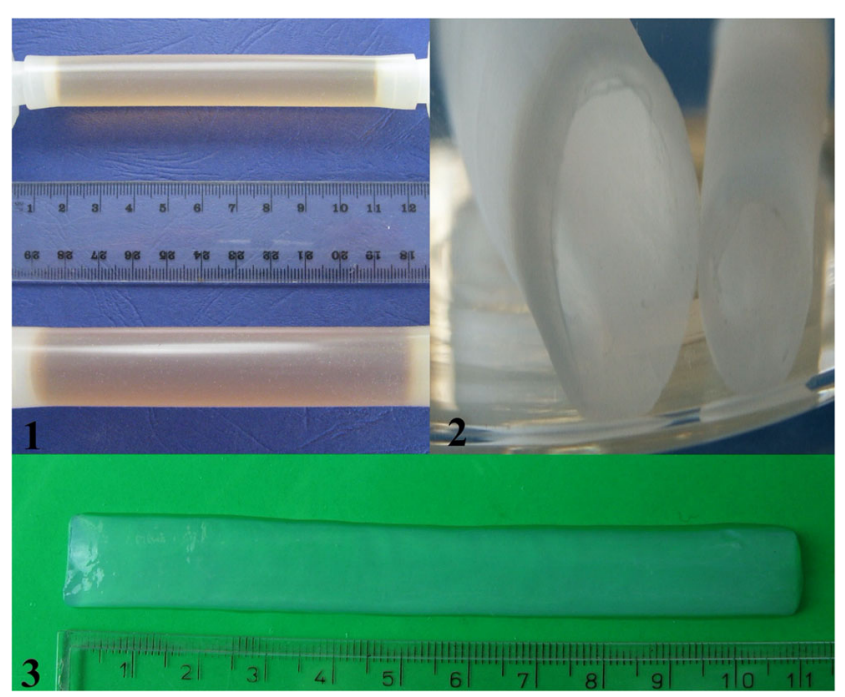

Fig. 1 Biosynthesis and morphology of $\mathrm{BC}$ tubes. Bacterial cellulose in tubular form was obtained by biosynthesis in silicone tubes (1.1). BC tubes used for testing with an external diameter of $10 \mathrm{~mm}$ and wall thickness of 1.7-1.8 mm (1.2 and 1.3). 

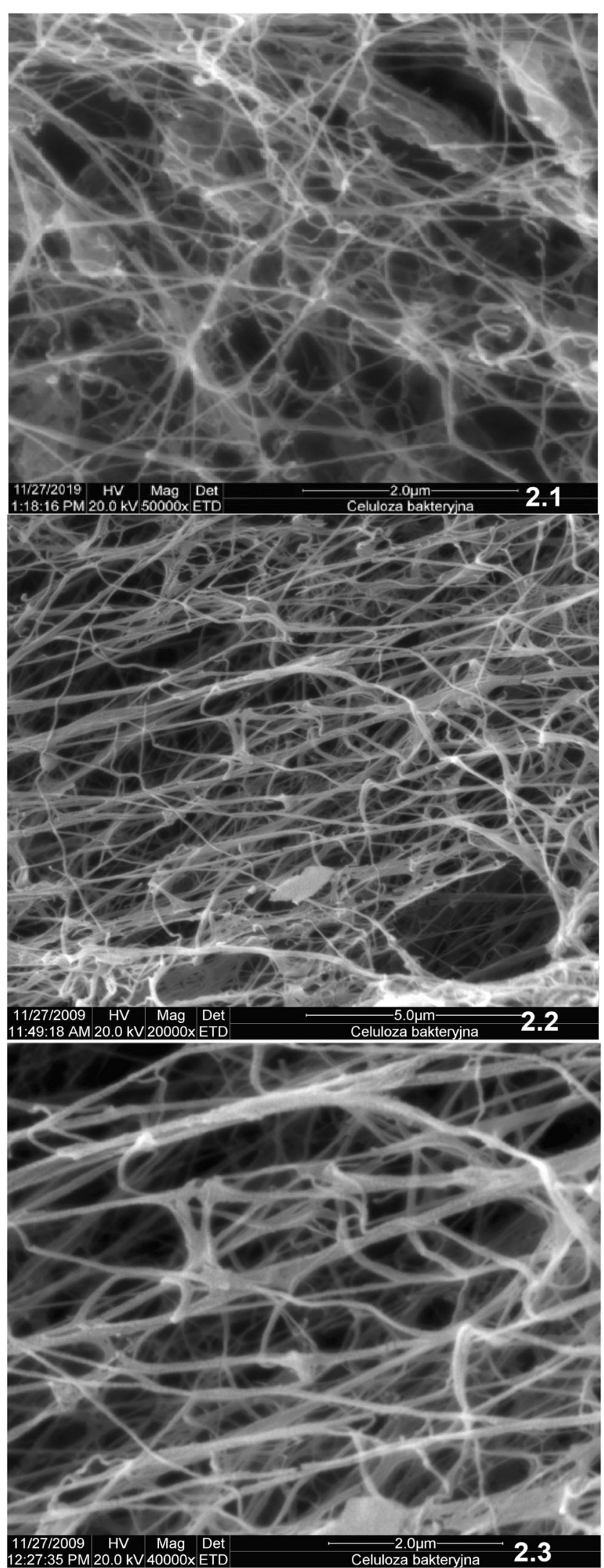

BCTube was shown. On Fig. 2b-c, 3 cross-section and layered growth of bacterial cellulose were presented.
Fig. 2 SEM image presenting the structure of BC tube produced by the static method; (2.1) internal wall surface of BCTube, magnification $\times 50,000$; (2.2) cross-section and layered growth of BCTube, magnification $\times 20,000$; (2.3) cross-section and layered growth of BC tube, magnification $\times 40,000$

The obtained $\mathrm{BC}$ tubes were washed with distilled water until the complete removal of culture medium components. Next, the tubes were soaked in $1 \% \mathrm{NaOH}$, autoclaved at 121 ${ }^{\circ} \mathrm{C}$ for $15 \mathrm{~min}$, and washed with distilled water until reaching neutral $\mathrm{pH}$ and conductivity $<20 \mu \mathrm{S}$.

\section{Hemocompatibility of BC Tubes}

The hemocompatibility tests of a modified bacterial cellulose blood vessel prosthesis were prepared on human blood $\mathrm{O} \mathrm{Rh}+$ taken into CPD preservative (sodium citrate, citric acid, glucose dihydrogen phosphate). The scope of work included the following:

1. Hemolytic activity study:

(a) After temporary contact with blood (plasma $\mathrm{Hb}$ determination)

(b) After temporary contact of the extract with the red blood cell suspension (determination of the hemolysis rate)

2. Tests of the plasma clotting system after temporary contact of full blood with the prosthesis:

(a) Determination of partial thromboplastin time after activation

(b) The indication of the prothrombin time

(c) Indication of thrombin time

(d) Determination of fibrinogen

\section{Experimental Section-Methods}

\section{In vitro Testing}

Mouse fibroblast cells were cultured on NUNC 12-well plates in density of $0.5 \cdot 10^{6}$. After $24 \mathrm{~h}$, the cells adhered to the plate's surface and divided, covering about $50 \%$ of the plate surface. After this time, the culture medium was removed and a new medium was added to each well. Samples of $5 \times 5 \mathrm{~mm}$ in size were applied to the cell cultures (the samples covered about $10 \%$ of the culture surface) and plates were incubated at $37^{\circ} \mathrm{C}$, in $5 \% \mathrm{CO} 2$ atmosphere. Quantitative and morphological changes, after contact with the examined materials, were evaluated after 24,48 , and $72 \mathrm{~h}$ under a reversed contrast-phase microscope. Trypan blue staining was used to determine the number of dead cells. The degree of toxicity of the materials was assessed on the basis of changes in cell morphology, their survival, and ability to proliferate according to the criteria given in Table 1 . 
Table 1 Degrees of direct contact toxicity test

\begin{tabular}{|c|c|c|}
\hline Degree & Toxicity & Description of changes in cell culture \\
\hline 0 & Lack & Single intracytoplasmic granules, no evidence of cell lysis \\
\hline 1 & Weak & $\begin{array}{l}\text { Approximately } 20 \% \text { of cells rounded, shrunken, detached from the } \\
\text { substrate, no cytoplasm densities were found, single cells disrupted }\end{array}$ \\
\hline 2 & Moderate & $\begin{array}{l}\text { Approximately } 50 \% \text { of cells rounded, no granulation were found, } \\
\text { extensive cell lysis and empty areas between cells }\end{array}$ \\
\hline 3 & Average & Approximately $70 \%$ rounded cells, cells licked \\
\hline 4 & Strong & Almost completely destroyed cell culture \\
\hline
\end{tabular}

\section{In vivo Testing}

Based on European Pharmacopoeia 6th edition and ISO 10993-1:2010 Biological evaluation of medical devices-Part 1: Evaluation and testing within a risk management process (ISO 10993-1:2009) guidelines for biological evaluation of MBC vascular prostheses, we have conducted the following tests:

- Acute oral toxicity test

- Intradermal reactivity test

- Guinea pig maximization test (GPMT)

- Histopathological evaluation of biocompatibility after implantation of $\mathrm{BC}$ tubes in animal body

\section{Toxicity Test}

The toxicological test was carried out in accordance with the requirements of OECD Guidelines for the testing of chemicals, section 4 Health Effects Test No. 425: acute oral toxicity: up-and-down procedure. The limit test is carried out on 5 animals, which are given a test substance of $2000 \mathrm{mg} / \mathrm{kg}$. If at least $3 / 5$ of the animals survive within 14 days, the LD50 is considered to be above $2000 \mathrm{mg} / \mathrm{kg}$. If $3 / 5$ of the animals die, the main test is carried out. If at least $3 / 5$ of the animals survive for 14 days, the LD50 is considered to be above 2000 $\mathrm{mg} / \mathrm{kg}$. If $3 / 5$ of the animals die, a further study is performed - the main test, consisting of administration of the following sequence of doses 1.75, 5.5, 17.5, 55, 175, 550 , and $2000 \mathrm{mg} / \mathrm{kg}$ (growth factor of successive doses 3.2 ) to individual animals at $24-\mathrm{h}$ intervals. If the first animal survives, the next one is given a higher dose. If after the next dose the animal dies or is in agonal condition, a lower dose is administered, between the lethal and non-lethal dose. Statistical evaluation of the test results is performed using the "Statistical Programme-AOT 425 StatPgm, Version: 1." The study used a suspension of fragmented lyophilizate of MBC. Biological-modified bacterial cellulose vascular prostheses were homogenized in distilled water, freeze-dried to remove water, ground, and then dried for $20 \mathrm{~h}$ at $105^{\circ} \mathrm{C}$. The material for testing was placed in polypropylene packages and secured against re-absorption of moisture by the material with parafilm. Thus prepared prostheses for testing were suspended in water for injections, thus forming a dense, gelatinous suspension. The suspension intended for administration with a stomach probe was obtained after adding up to $1000 \mathrm{mg}$ of cellulose $12.5 \mathrm{ml}$ of water. Injection water "aqua pro injection" was used for the doses. $(500 \mathrm{ml}$, Series No.: 0907404, Manufacturer Baxter Manufacturing Sp. z o.o.). The study was conducted on ten white Imp:WIST rats (five males and five females). Prior to the application of doses, the body mass of the animals was accurately determined. Bacterial cellulose suspension at a dose of $2 \mathrm{~g} / \mathrm{kg}$ b.w was administered through a probe into the stomach. Due to the fact that the quantity of the administered suspension exceeded 2 $\mathrm{ml} / 100 \mathrm{~g}$ b.w. (OECD guidelines), the substance was administered in two equally divided portions at an interval of four hours (0900 and 1300). The total amount of administered cellulose dispersion was $2.5 \mathrm{ml} / 100 \mathrm{~g}$ b.w. $=0.2 \mathrm{~g} / 100 \mathrm{~g}$ m.c, which corresponds to a dose of $2 \mathrm{~g} / \mathrm{kg}$ b.w. Consecutive observations were performed twice a day. The body weight of rats was determined 3, 7, and 14 days after treatment, as stated in OECD guidelines No. 425. The scope of animal observations was as follows: autonomic and central nervous system, respiratory system, and circulatory system, as well as the skin, fur, eyes, and mucous membranes. Attention was drawn to the occurrence of tremors, convulsions, salivation, diarrhea, lethargy, and coma. Somatomotor activity and behavior were also evaluated.

\section{Intradermal Reactivity Test}

The study used three rabbits Imp:BN. Two extracts were prepared: nonpolar in cottonseed oil and polar in isotonic sodium chloride solution (which are substances of choice in our lab for this procedure), according to ISO 10993-12:2012.

Intracutaneous injections with $0.2 \mathrm{ml}$ of the extract obtained with polar or non-polar solvent at five sites were performed on the left part of each rabbit. Similarly, the right side was injected with polar or non-polar solvent control as shown in Fig. 4. Observations were performed immediately after injection and at 24,48 , and $72 \mathrm{~h}$, as well as 4 and 5 days after injection. 


\section{Guinea Pig Maximization Test (GPMT)}

The maximization test was conducted according to the OECD Guidelines for the Testing of Chemicals, Section 4 Health Effects Test No. 406: Skin Sensitization of Magnusson and Kligman and based on ISO 10993: 10; 2011 [12]. On the day before investigation, the fur was removed from dorsal area of the guinea pigs on both sites of the trunk, without injuring the skin. Then, on the first day of the induction period, three pairs of intradermal injections $(0.1 \mathrm{ml} / \mathrm{site})$ were performed in the scapular area (Fig. 5). On day 8 of the experiment, $0.5 \mathrm{~g}$ of $10 \%$ sodium lauryl sulfate in vaseline was applied on the right site of all guinea pigs to evoke local inflammation, and these areas were washed after $24 \mathrm{~h}$. Next, a sterile gauze compress with $0.5-\mathrm{ml}$ analyzed water extract was applied to the exposed skin, stabilized with a bandage and left for $48 \mathrm{~h}$. On day 22 of the study, a sensitization reaction was induced in all guinea pigs.

Checking test for sensitization was performed after $24 \mathrm{~h}$. The effects of sensitization were evaluated according to the Magnusson-Kligman Classification 48, 72, and $96 \mathrm{~h}$ following the sensitization reaction.

\section{Implantation}

The examination was carried out in accordance with the requirements of ISO 30993:6 2009. Thirty male white rats were used in the vascular prosthesis testing. With the animals under deep anesthesia $(80-100 \mathrm{mg} / \mathrm{kg}$ ketamine hydrochloride i.p.; Sigma Aldrich Sp. z.o.o, Poland), the tested implants were inserted into the pocket of panniculus camosus muscles along the dorsal midline, and kept there for 1 month (vascular prosthesis). Following this time, a block measuring $2 \mathrm{~cm} \times 2 \mathrm{~cm}$ from the point of entry of the implant (cervical-interscapular region) was resected. This sample covered the entire thickness of the back muscles.

\section{Histopathological Evaluation After Implantation of Vascular Prosthesis of Chitosan-Modified Bacterial Cellulose}

The examination was carried out in accordance with the requirements of ISO 30993:6; 2009. The muscle sections were dehydrated in increasing concentrations of alcohol and imbued with paraffin in an RVG/1 computer tissue processor (Belair Instrument Company). Microscopic samples of 4$6 \mu \mathrm{m}$ thickness were prepared on an MH-325 rotary microtome (Thermo Scientific ${ }^{\mathrm{TM}}$ ) and stained with hematoxylin and eosin in a Varistain Gemini staining machine (Varistain ${ }^{\mathrm{TM}}$ Gemini ES Automated Slide Stainer A78000014). In addition, samples were stained in acidic fuchsin in picric acid in order to visualize collagen fibers.

After removal of the implants, two assessments of the rats' entrails were conducted: evaluation of the internal organs and their blood supply and a macroscopic examination of the muscles surrounding the implants and of the stomach, liver, and kidneys.

\section{Statistical Analysis}

The statistical analysis of in vitro testing results was performed using the Student's $t$-test. The correlation coefficient was assumed to be significant at $* p<0.05,{ }^{* *} p<0.01,{ }^{* * *} p<0.001$.

In comparing the results obtained by in vivo testing, the chi-square test with Fisher's exact test were used to determine whether the differences in scores between the tested animals or sites and respective controls were significant. The differences in the number of responses of the test site/group versus the control site/group were compared using the MannWhitney $U$ test. Differences were considered significant for $p<0.05$. Statistical analysis of the results was performed with Statistica software for Windows (v.12 StatSoft, Inc., Tulsa, OK, USA).

\section{Results}

\section{Physical-Mechanical Properties of BC Tubes}

Figure 3 shows the spectra for bacterial cellulose without modification; chitosan oligomers used to modify $\mathrm{BC}$ tubes and modified bacterial cellulose- $\mathrm{BC}$ tube. A wide band at $3400 \mathrm{~cm}^{-1}$, attributed to the stretching vibration of the $\mathrm{OH}$ (connected by hydrogen bond) and/or NH group, could be observed in the all spectra. A band within the range 2800 $2950 \mathrm{~cm}^{-1}$ corresponding to the stretching vibration of the C$\mathrm{H}$ bond - characteristic for both polysaccharides - also could be observed. Because during biosynthesis the nutrition medium was modified by chitosan oligomers, also the bands characteristic for chitosan oligomers corresponding to the stretching vibration of the $\mathrm{C}=\mathrm{O}$ bond in primary amides detected in $1630-1660 \mathrm{~cm}^{-1}$, was observed also in $\mathrm{BC}$ tubes structure. A band at $1320 \mathrm{~cm}^{-1}$ observed in chitosan oligomers and $\mathrm{BC}$ tube corresponds to $\mathrm{C}-\mathrm{N}$ stretching of amide III. A band at $1550 \mathrm{~cm}^{-1}$ corresponding to $\mathrm{N}-\mathrm{H}$ bending of amide II was observed in chitosan oligomers, but not in BC tube. Probably it was overlapped by other bands.

The $\mathrm{BC}$ tubes were found to possess the following physical-mechanical properties:

- Length 10-12 cm

- Surface density of about $10 \mathrm{~g} / \mathrm{m}^{2}$ (of dry cellulose)

- Selected molecular parameters of bacterial cellulose (GPC/SEC analysis according to the Turbak procedure $[10,11])$ : number average molar mass Mn $150 \mathrm{kD}$, mass average molar mass Mw $310 \mathrm{kDa}$, average polymerization degree equal to 1954 


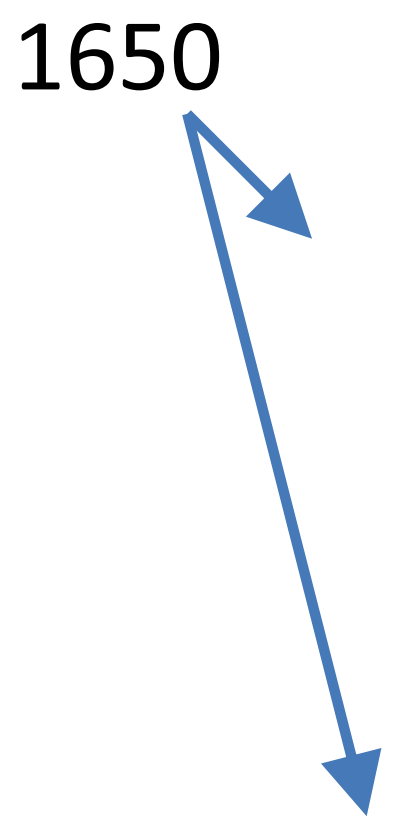

\section{0}
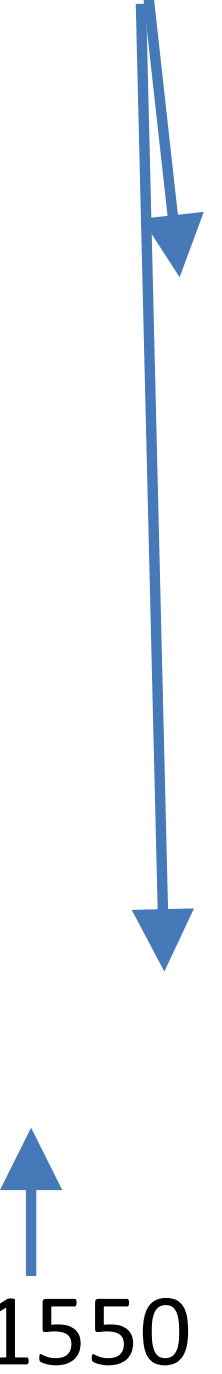

Fig. 3 Fourier transform infrared spectroscopy (FTIR) analysis of investigated. Samples detecting structures characteristic for saccharide structures and chitosan oligomers

- Peripheral tenacity of approximately $14.5 \mathrm{cN} / \mathrm{mm}$, (according ISO 7198:1998)

- A longitudinal tenacity of approximately $930 \mathrm{cN}$, (according to ISO 7198:1998)

- A suture retention strength of $50 \mathrm{cN}$, (according to ISO 7198:1998)

- Water permeability below $1 \mathrm{ml} / \mathrm{min}^{2} \mathrm{~cm}^{2}$ at a pressure of $120 \mathrm{~mm} \mathrm{Hg}$ (according to ISO 7198)

- Content of nitrogen: 0,16mg/g BCTube (Vario Macro Cube analyzer).

- Endotoxin content-1.25 EU/product-semi-quantitative gel test LAL (limulus amebocyte lysate) (according to US Pharmacopeia 27). The permissible level of endotoxin content according to USP 27 is $20 \mathrm{EU} /$ product

\section{Biocompatibility of BC Tubes}

\section{In Vitro Testing of Cytotoxic Action: fControl Cell Cultures}

After 24,48 , and $72 \mathrm{~h}$ in control cultures, the cells adhered to the medium and had proper morphological features. No agglutination, vacuolization, separation from the medium, or lysis of cell membranes was found. Cell proliferation was normal. The cells formed colonies, which covered the whole plate. After $72 \mathrm{~h}$ in control cultures, $1 \%$ of dead cells were found.

\section{Cultures with Vascular Prosthesis Samples from Modified Bacterial Cellulose (MBC)}

In cultures with modified cellulose samples, at all testing times, the cells adhered to the substrate and had correct morphological characteristics. No agglutination, vacuolization, separation from the background, or lysis of cell membranes was found. Cell proliferation after 24, 48, and $72 \mathrm{~h}$ was insignificantly lower compared to cell proliferation in control cultures. After $48 \mathrm{~h}$ in cultures with samples $2 \%$ of the cells were dead and after $72 \mathrm{~h} 5 \%$ of the cells were dead (Table 2, Fig. 6).

\section{Hemocompatibility}

In the study of hemolytic activity using concentrated red blood cells, which come into contact with both the material under evaluation and its extract in physiological saline, the average value of hemolysis percentage was $0.25 \pm 0.06 \%$. The obtained value did not exceed the value allowed by the standard, i.e., $3 \%$; in full blood hemolytic activity tests (CPD), having direct contact with the surface of the material, the mean value of hemolysis percentage was $0.14 \pm 0.03 \%$. The obtained value did not exceed the value acceptable by the standard, i.e., $1 \%$; in tests of plasma clotting system, significant $(p<0.05)$ shortening of prothrombin time (PT) with unchanged values of partial thromboplastin time after activation (APTT) was found within $2 \mathrm{~h}$ of blood contact with the material. However, after $24 \mathrm{~h}$, APTT and PT were prolonged. The thrombin time (TT) values were prolonged and fibrinogen concentration decreased. It follows that the grafts made of modified bacterial cellulose activates to some extent the blood clotting process. However, the observed changes in the values of the determined clotting system parameters do not exceed the range of reference values. These changes may be due to the effect of material components on the coagulation factors of both the intra- and extra-transmitted system as well as to the conversion of fibrinogen into fibrin. The activation of the clotting system by the material under assessment is evidenced by shortened clotting time of whole blood after calcification. 
Fig. 4 Location of skin application sites for Intradermal Reactivity Test

Fig. 5 Schematic illustration of Guinea pig maximization test

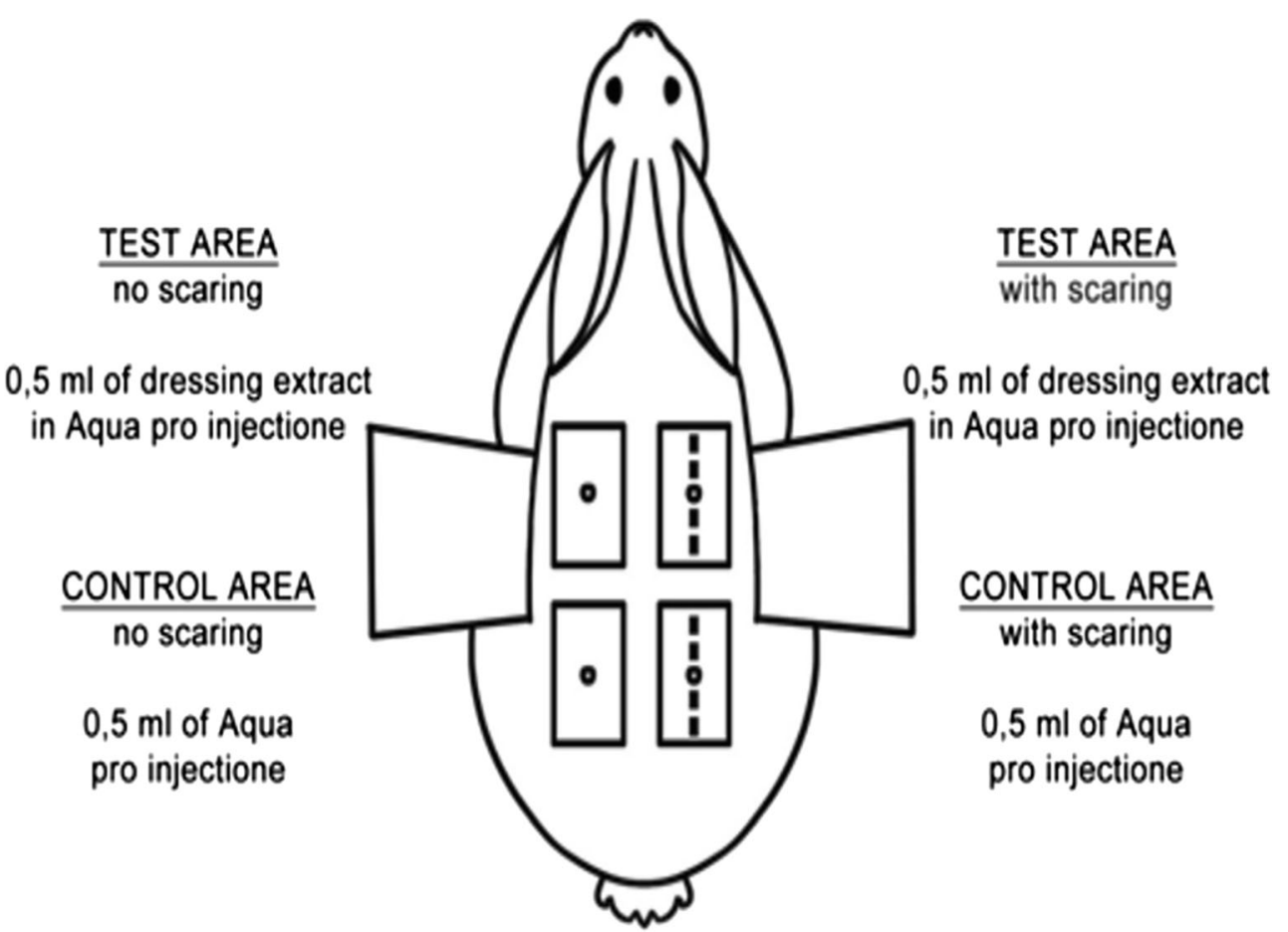

INDUCTION

Intradermal
injection - Day

- 1 inj. $0.1 \mathrm{ml}$ mixture 1:1 (v/v) $\mathrm{FCA}+$ water (vehicle)

- 2 inj. $0.1 \mathrm{ml}$ extract material in water (vehicle)

- 3 inj. $0.1 \mathrm{ml}$ extract material

in mixture $\mathrm{FCA} /$ water 1:1 (v/v)

Test animals $\mathrm{n}=10$

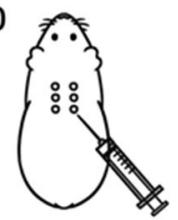

- 1 inj. $0.1 \mathrm{ml}$ mixture 1:1 (v/v) FCA + water (vehicle)

- 2 inj. $0.1 \mathrm{ml}$ water (vehicle)

- 3 inj. $0.1 \mathrm{ml} \mathrm{50 \% (w/v)}$ mixture of water (vehicle) in $1: 1(\mathrm{v} / \mathrm{v}) \mathrm{FCA} /$ water

\section{Control animals}

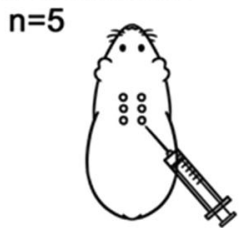

Topical

application - Day 8

$0.5 \mathrm{ml}$ extract material

application with

a patch for $48 \mathrm{~h}$

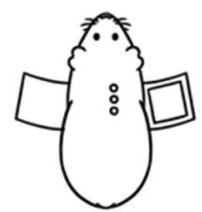

$0.5 \mathrm{ml}$ water vehicle application with a patch for $48 \mathrm{~h}$

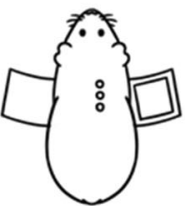

CHALLENGE

Sensitization

reaction - Day 22

$0.5 \mathrm{ml}$ extract material application on right site and water vehicle on left site

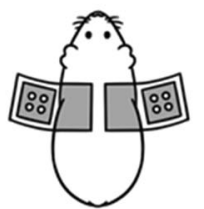

$0.5 \mathrm{ml}$ extract material application on right site and water vehicle on left site

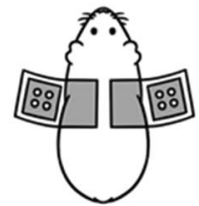

CHECKING TEST

Patch test Days 23-24 observation and grading skin reactions

SCALE 0-3

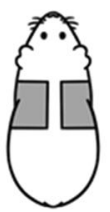

observation and grading skin reactions

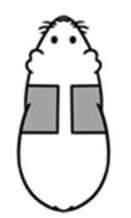


Table 2 Cytotoxic changes in 3T3Balb/C mouse fibroblast in control cultures and cultures with vascular prosthesis samples from modified bacterial cellulose (MBC)

\begin{tabular}{|c|c|c|c|c|c|c|c|c|c|}
\hline \multirow{2}{*}{$\begin{array}{l}\text { Cell } \\
\text { culture }\end{array}$} & \multicolumn{3}{|l|}{$24 \mathrm{~h}$} & \multicolumn{3}{|l|}{$48 \mathrm{~h}$} & \multicolumn{3}{|l|}{$72 \mathrm{~h}$} \\
\hline & $\begin{array}{l}\text { Density of cells/ } \\
\mathrm{ml} \times 10^{6}\end{array}$ & $\begin{array}{l}\text { Dead cells } \\
{[\%]}\end{array}$ & $\begin{array}{l}\text { Degree of } \\
\text { toxicity }\end{array}$ & $\begin{array}{l}\text { Density of cells/ } \\
\mathrm{ml} \times 10^{6}\end{array}$ & $\begin{array}{l}\text { Dead cells } \\
{[\%]}\end{array}$ & $\begin{array}{l}\text { Stopień } \\
\text { toksyczności }\end{array}$ & $\begin{array}{l}\text { Density of cells/ } \\
\mathrm{ml} \times 10^{6}\end{array}$ & $\begin{array}{l}\text { Dead cells } \\
{[\%]}\end{array}$ & $\begin{array}{l}\text { Degree of } \\
\text { toxicity }\end{array}$ \\
\hline Control & $0.82 \pm 0.025$ & 0 & 0 & $1.26 \pm 0.023$ & 0 & 0 & $1.86 \pm 0.032$ & 1 & 0 \\
\hline $\mathrm{MBC}$ & $\begin{array}{l}0.78 \pm 0.02 \\
p=0.068\end{array}$ & 0 & 0 & $\begin{array}{l}1.22 \pm 0.04 \\
p=0.211\end{array}$ & 2 & 0 & $\begin{array}{l}1.78 \pm 0.036 \\
p=0.058\end{array}$ & 5 & 0 \\
\hline
\end{tabular}

\section{Toxicity Test}

No pathological signs were observed in the fur, orifices, eyes, muscle tension, or behavior of three males and three females immediately after administration of modified BC suspension. After 1 day, female no. 65 was less mobile; there was a clear tilt of the head to the right and increased tension in the neck muscles. After 2 days, the tested female died. Based on clinical observations and the results of the post-mortem examination, it was assumed that the cause of rat's death was a lesion of the esophagus wall during administration of the test substance. Death was then assessed not be related to the toxic effects of tested implants. All of the remaining animals survived the period of 14 days of observation (five males and four females). Constant weight gain was found (Table 3). No signs of pathology were found regarding animal behavior, evaluation of hair in natural orifices of the body, the appearance of the eyes, or muscle tension. The autopsy found the structure and blood supply to the internal organs to be normal. The macroscopic image of the gastric area and small and large bowel was within normal limits. No pathological signs regarding animal behavior, hair, orifices, the eyes, or muscle tension were noted within 14 days. Detailed results of sectional studies was presented in Table 4.

\section{Intradermal Reactivity Test}

The results are presented in Table 5. The non-polar and polar extracts of modified bacterial cellulose implants revealed mild erythema in one out of three rabbits after 24 hours of examination time after 48 hours, this erythema disappeared. No significant changes in intradermal reactivity were observed. The Primary Irritation Index was found to be 0.03 : The product is not irritating.

\section{Guinea Pig Maximization Test (GPMT)}

The detailed results are presented in Table 6. According to Chapter 3.4, Respiratory or Skin Sensitization, GHS guidelines, and substances which test maximize Magnusson and Kligman cause an allergic reaction less than $30 \%$ of the test animals should not pose a risk of allergic reactions in humans and should not be classified as substances with sensitizing properties (Global System for harmonization of classification and labeling of chemicals, United Nations, New York and Geneva, 2003). Therefore, it is considered that medical devices - biological vascular prostheses with modified bacterial cellulose - should not pose a risk for allergic reactions in humans.

\section{Histopathology}

Histopathological studies showed that the implanted vascular implants induced an initial inflammatory response which developed into a chronic inflammatory immune response known as host foreign body reaction (FBR). The classic host response is generally divided into several stages, from the formation of the wound during implant placement to the wound healing period. The final host response reaches a relative impasse with most implants, unresolved in chronic inflammation as long as the implant remains. This final condition is defined by the long-term presence of both activated macrophages and the associated giant foreign body cells (FBGC) at the tissue/ implant interface and the formation of a dense fibrous collagen capsule around the implant. These two characteristics - the presence of FBGC and the thickness of the fibrous

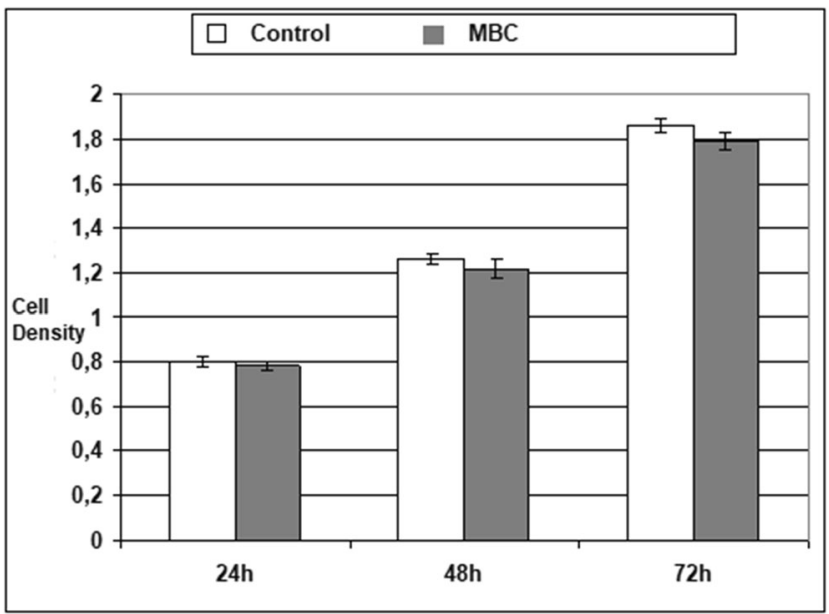

Fig. 6 Proliferation rates in 3T3Balb/C mouse fibroblast in control cultures and cultures with vascular prosthesis samples from modified bacterial cellulose (MBC). 
Table 3 Body weight measurements of rats after intragastric administration of the suspension of fragmented lyophilizate of biological vascular prostheses from chitosanmodified bacterial cellulose (MBC) for acute oral toxicity testing

\begin{tabular}{llllll}
\hline $\begin{array}{l}\text { Rat's } \\
\text { gender }\end{array}$ & No & \multicolumn{3}{l}{ Body mass of observed rats (grams) } \\
\cline { 3 - 6 } & & $\begin{array}{l}\text { Before } \\
\text { application } \\
\text { of MBC }\end{array}$ & $\begin{array}{l}\text { Observation } \\
\text { day } 3\end{array}$ & $\begin{array}{l}\text { Observation } \\
\text { day } 7\end{array}$ & $\begin{array}{l}\text { Observation } \\
\text { day } 14\end{array}$ \\
\hline Male & 1 & $300 \mathrm{~g}$ & $320 \mathrm{~g}$ & $340 \mathrm{~g}$ & $350 \mathrm{~g}$ \\
& 2 & $340 \mathrm{~g}$ & $360 \mathrm{~g}$ & $360 \mathrm{~g}$ & $380 \mathrm{~g}$ \\
& 3 & $300 \mathrm{~g}$ & $330 \mathrm{~g}$ & $340 \mathrm{~g}$ & $360 \mathrm{~g}$ \\
& 4 & $360 \mathrm{~g}$ & $370 \mathrm{~g}$ & $375 \mathrm{~g}$ & $395 \mathrm{~g}$ \\
& 5 & $350 \mathrm{~g}$ & $355 \mathrm{~g}$ & $360 \mathrm{~g}$ & $380 \mathrm{~g}$ \\
& 6 & $210 \mathrm{~g}$ & Death on observation day 2 & - & - \\
& 7 & $215 \mathrm{~g}$ & $230 \mathrm{~g}$ & $240 \mathrm{~g}$ & $250 \mathrm{~g}$ \\
& 8 & $225 \mathrm{~g}$ & $225 \mathrm{~g}$ & $245 \mathrm{~g}$ & $250 \mathrm{~g}$ \\
& 9 & $210 \mathrm{~g}$ & $220 \mathrm{~g}$ & $220 \mathrm{~g}$ & $240 \mathrm{~g}$ \\
& 10 & $210 \mathrm{~g}$ & $210 \mathrm{~g}$ & $235 \mathrm{~g}$ & $245 \mathrm{~g}$ \\
\hline
\end{tabular}

Table 4 Results of sectional studies

Rat Code: Sex: male. Body weight $350 \mathrm{~g}$

92 Clinical data: no signs of pathology were found in animal behavior, hair, natural body orifices, eyes, and muscle tension during 14 days of observation

Method of euthanasia: ether anesthetic, bleeding through femoral vessels

Thoracic and abdominal organ system is normal. Air lungs, chest filling, gray-pink surface

The liver is dark red in color, red on the cross sections with correct lobular pattern. Medium-sized spleen of dark red color. Stomach filled with greenish, dense food content. After cutting, the pre-stomach mucosa is grayish-white in color; the glandular part is grayish-white, light red in color with correct picture. The small and large intestine contains semi-liquid, brown food, gray-pink mucous membrane

Rat Sex: male. Body weight $380 \mathrm{~g}$

Code:57 Clinical data: no signs of pathology were found in animal behavior, hair, natural body orifices, eyes and muscle tension during 14 days of observation.

Method of euthanasia: ether anesthetic, bleeding through femoral vessels

Thoracic and abdominal organ system is normal. Air lungs, chest filling, gray-pink surface

The liver is dark red in color, red on the cross sections with correct lobular pattern. Medium-sized spleen, dark red in color. Stomach filled with greenish, dense food content. After cutting, the pre-stomach mucosa is grayish-white in color; the glandular part is grayish-white, light red with a correct picture

The small and large intestine contains semi-liquid, brown food, grey-pink mucous membrane

Rat Code: Sex: male. Body weight $350 \mathrm{~g}$

43 Clinical data: during 14 days of observation, no signs of pathology were found in animal behavior, assessment of coat, natural body orifices, eyes, and muscle tension

Method of euthanasia: ether anesthetic, bleeding through femoral vessels

Thoracic and abdominal organ system is normal. Air lungs, chest filling, gray-pink surface

The liver is dark red in color, red on the cross sections with correct lobular pattern. Medium-sized spleen, dark red in color. Stomach filled with greenish, dense food content. After cutting, the pre-stomach mucosa is grayish-white in color; the glandular part is grayish-white, light red in color with correct picture. The small and large intestine contains semi-liquid, brown food, gray-pink mucous membrane

Rat Code: Sex: male. Body weight $395 \mathrm{~g}$

62 Clinical data: no pathological signs were found in animal behavior, hair, natural body orifices, eyes, and muscle tension during 14 days of observation

Method of euthanasia: ether anesthetic, bleeding through femoral vessels

Thoracic and abdominal organ system is normal. Air lungs, chest filling, gray-pink surface

The liver is dark red in color, red on the cross sections with correct lobular pattern. Medium-sized spleen, dark red in color. Stomach filled with greenish, dense food content. After cutting the pre-stomach mucous membrane is grayish-white in color; the glandular part is grayish-white, light red with correct drawing

The small and large intestine contains semi-liquid brown food, gray-pink mucous membrane

Rat Code: Sex: male. Body weight $350 \mathrm{~g}$

35 Clinical data: no signs of pathology were found in animal behavior, hair, natural body orifices, eyes, and muscle tension during 14 days of observation

Method of euthanasia: ether anesthetic, bleeding through femoral vessels 
Table 4 (continued)

Rat Code: Sex: male. Body weight $350 \mathrm{~g}$

92 Clinical data: no signs of pathology were found in animal behavior, hair, natural body orifices, eyes, and muscle tension during 14 days of observation

Method of euthanasia: ether anesthetic, bleeding through femoral vessels

Thoracic and abdominal organ system is normal. Air lungs, chest filling, gray-pink surface

The liver is dark red in color, red on the cross sections with correct lobular pattern. Medium-sized spleen of dark red color. Stomach filled with greenish, dense food content. After cutting, the pre-stomach mucosa is grayish-white in color; the glandular part is grayish-white, light red in color with correct picture. The small and large intestine contains semi-liquid, brown food, gray-pink mucous membrane

Thoracic and abdominal organ system is normal. Air lungs, chest filling, gray-pink surface

The liver is dark red in color, red on the cross sections with correct lobular pattern. Medium-sized spleen, dark red in color. Stomach filled with greenish, dense food content. After cutting, the pre-stomach mucosa is grayish-white in color; the glandular part is grayish-white, light red in color with correct picture. The small and large intestine contains semi-liquid brown food, gray-pink mucous membrane

Rat Code: $\quad$ Sex: female. Body weight $210 \mathrm{~g}$

85 Clinical data: 26.10. Normal behavior. 27.10 Female, less mobile, clear head-tilt to the right, increased neck muscle tension

Died: 28.10 .09

Thoracic and abdominal organ system normal. Lungs sunken, not very airy, greyish-red surface with clearly marked widening of blood vessels (congestion). The liver is dark red in color, red on the cross sections with correct lobular pattern. Medium sized spleen, dark red in color. The esophagus is empty, after cutting with red, congested mucous membrane. The stomach is filled with a small amount of greenish, nutritious content. After the intersection, the pre-stomach mucosa is grayish-white in color; the glandular part is grayish-white, light red with a correct figure. The small and large intestine is bloated, contains liquid brown food; the mucous membrane is greyish-red, bloodied

Rat $\quad$ Sex: female. Body weight $250 \mathrm{~g}$

Code:58 Clinical data: no signs of pathology were found in animal behavior, coat evaluation, natural body orifices, eyes, and muscle tension during 14 days of observation

Method of euthanasia: ether anesthetic, bleeding through femoral vessels

Thoracic and abdominal organ system is normal. Air lungs, chest filling, gray-pink surface

The liver is dark red in color, red on the cross sections with correct lobular pattern. Medium-sized spleen, dark red in color. Stomach filled with greenish, dense food content. After cutting, the pre-stomach mucosa is grayish-white in color; the glandular part is greyish-white, light red in color with correct picture. The small and large intestine contains semi-liquid brown food, gray-pink mucous membrane

Rat Sex: female. Body weight $250 \mathrm{~g}$

Code:60 Clinical data: during 14 days of observation, no signs of pathology were found in animal behavior, assessment of hair, natural body orifices, eyes, and muscle tension

Method of euthanasia: ether anesthetic, bleeding through femoral vessels

Thoracic and abdominal organ system is normal. Air lungs, chest filling, gray-pink surface. The liver is dark red in color, red on the cross sections with correct lobular pattern. Medium-sized spleen, dark red in color. Stomach filled with greenish, dense food content. After cutting, the pre-stomach mucous membrane is grayish-white in color; the glandular part is grayish-white, light red with correct drawing. The small and large intestine contains semi-liquid brown food, grey-pink mucous membrane

Rat Sex: female. Body weight $240 \mathrm{~g}$

Code:32 Clinical data: no signs of pathology were found in animal behavior, hair, natural body orifices, eyes and muscle tension during 14 days of observation.

Method of euthanasia: ether anesthetic, bleeding through femoral vessels

Thoracic and abdominal organs system is normal. Air lungs, chest filling, gray-pink surface

Liver is dark red in color, red on the cross sections with correct lobular pattern. Medium sized spleen, dark red in color. Stomach filled with greenish, dense food content. After cutting the pre-stomach mucous membrane is grayish-white in color; the glandular part is greyish-white, light red with correct drawing. The small and large intestine contains semi-liquid brown food, gray-pink mucous membrane

Rat Sex: female. Body weight $245 \mathrm{~g}$

Code:36 Clinical data: no signs of pathology were found in animal behavior, hair, natural body orifices, eyes, and muscle tension during 14 days of observation.

Method of euthanasia: ether anesthetic, bleeding through femoral vessels

Thoracic and abdominal organ system is normal. Air lungs, chest filling, gray-pink surface. The liver is dark red in color, red on the cross sections with correct lobular pattern. Medium-sized spleen, dark red in color. Stomach filled with greenish, dense food content. After cutting, the pre-stomach mucous membrane is grayish-white in color; the glandular part is grayish-white, light red with correct drawing. The small and large intestine contains semi-liquid brown food, gray-pink mucous membrane

capsule - are characteristic for the evaluation of the FBR. Chronic local condition remains for the whole period of implantation. The implant morphology and biomaterial as well as location of the implant determine the host's response to the implant which is not dependent on the chemical composition of the material, the size of the implant, and method of 
Table 5 Total summary of results of the study of reactivity intradermal extract of polar and of non-polar extract of biological vascular prostheses from chitosan-modified bacterial cellulose

\begin{tabular}{lllllll}
\hline & \multicolumn{2}{l}{ Rabbit No. 107} & & \multicolumn{2}{l}{ Rabbit No. 91} & \multirow{2}{*}{ Rabbit No. 96} \\
\cline { 2 - 3 } Index & The sum of points & Average & & The sum of points & Average & The sum of points \\
\hline PEN & 3 & 0,1 & & 0 & 0 & 0 \\
PKN & 0 & 0 & 0 & 0 & 0 \\
PEP & 3 & 0,1 & 0 & 0 & 0 \\
PKP & 0 & 0 & 0 & 0 & 0 \\
PEN-PKN & 3 & 0,1 & 0 & 0 & 0 \\
PEP-PKP & 3 & 0,1 & 0 & 0 & 0 \\
PIS & 0.1 & & 0 & & 0 \\
PII & 0.03 & & & & \\
\hline
\end{tabular}

The sum, sum of points the severity of redness (erythema) and swelling of the skin (30 readings).

$P E N$, points of non-polar extract (in cottonseed oil)

$P K N$, points of control non-polar extract (cottonseed oil)

$P E P$, points of polar extract (in $0.9 \%$ sodium chloride)

$P K P$, points of the control polar extract ( $0.9 \%$ sodium chloride)

$P I S$, the main point of irritation; $\mathrm{PIS}=(\mathrm{PEN}-\mathrm{PKN})+(\mathrm{PEP}-\mathrm{station}) / 2$

$P I I$, the primary irritation index; $\mathrm{PII}=\left(\mathrm{PIS}^{\prime}+\mathrm{PIS}^{\prime}\right) / 3$ introduction. The study was conducted on outbred Stock Han Wistar Imp:WIST rats due to the possibility of extrapolating the results to human populations.

In microscopic view, implants of modified bacterial cellulose were visible as an amorphous, fibrillar structure. The implants were placed between the muscles of the back, the epimysium, and intramuscularly (Fig. 7.1, 7.2, and 7.3). In all animals, the implants were surrounded by connective capsule (Fig. 7.4, 7.5, and 7.6 and Fig. 8.1 and 8.2) formed by histiocytes and fibroblasts (Fig. 7.4 and 7.5) and collagen fibers (Fig. 8.1 and 7.8). The implants placed under the epimysium produced a significant thickening of the connective capsule over the implant (Fig. 7.1). In all cases, vascular-connective tissue strands grew from the inside of the capsule into the implants (Fig. 7.1, 7.2, 7.3, and 7.6). These bands were made of collagen fibers (Fig. 8.2), blood vessels, histiocytes and fibroblasts (Fig. 7.6 and Fig. 7.7). In the

Table 6 Skin sensitization test results

\begin{tabular}{|c|c|c|c|c|c|c|c|c|c|c|c|c|c|c|}
\hline \multirow[t]{2}{*}{ Guinea pig code } & \multirow[t]{2}{*}{ Observation time (h) } & \multicolumn{3}{|c|}{$\begin{array}{l}\text { Microbial cellulose } \\
\text { prostheses extract }\end{array}$} & \multicolumn{3}{|c|}{$\begin{array}{l}\text { Aqua pro } \\
\text { injection }\end{array}$} & \multirow[t]{2}{*}{ Guinea pig code } & \multirow[t]{2}{*}{ Observation time (h) } & \multicolumn{3}{|c|}{$\begin{array}{l}\text { Microbial cellulose } \\
\text { prostheses extract }\end{array}$} & \multicolumn{2}{|c|}{$\begin{array}{l}\text { Aqua pro } \\
\text { injection }\end{array}$} \\
\hline & & $\mathrm{E}$ & $\mathrm{O}$ & $\mathrm{D}$ & $\mathrm{E}$ & $\mathrm{O}$ & $\mathrm{D}$ & & & $\mathrm{E}$ & $\mathrm{O}$ & $\mathrm{D}$ & $\mathrm{E}$ & $\mathrm{O}$ \\
\hline \multirow[t]{3}{*}{165} & 48 & 0 & 0 & 0 & 0 & 0 & 0 & 158 & 48 & 0 & 0 & 0 & 0 & 0 \\
\hline & 72 & 0 & 0 & 0 & 0 & 0 & 0 & & 72 & 0 & 0 & 0 & 0 & 0 \\
\hline & 96 & 0 & 0 & 0 & 0 & 0 & 0 & & 96 & 0 & 0 & 0 & 0 & 0 \\
\hline \multirow[t]{3}{*}{154} & 48 & 0 & 0 & 0 & 0 & 0 & 0 & 139 & 48 & 0 & 0 & 0 & 0 & 0 \\
\hline & 72 & 0 & 0 & 0 & 0 & 0 & 0 & & 72 & 0 & 0 & 0 & 0 & 0 \\
\hline & 96 & 0 & 0 & 0 & 0 & 0 & 0 & & 96 & 0 & 0 & 0 & 0 & 0 \\
\hline \multirow[t]{3}{*}{167} & 48 & 0 & 0 & 0 & 0 & 0 & 0 & 149 & 48 & 0 & 0 & 0 & 0 & 0 \\
\hline & 72 & 0 & 0 & 0 & 0 & 0 & 0 & & 72 & 0 & 0 & 0 & 0 & 0 \\
\hline & 96 & 0 & 0 & 0 & 0 & 0 & 0 & & 96 & 0 & 0 & 0 & 0 & 0 \\
\hline \multirow[t]{3}{*}{164} & 48 & 0 & 0 & 0 & 0 & 0 & 0 & 153 & 48 & 0 & 0 & 0 & 0 & 0 \\
\hline & 72 & 0 & 0 & 0 & 0 & 0 & 0 & & 72 & 0 & 0 & 0 & 0 & 0 \\
\hline & 96 & 0 & 0 & 0 & 0 & 0 & 0 & & 96 & 0 & 0 & 0 & 0 & 0 \\
\hline \multirow[t]{3}{*}{132} & 48 & 0 & 0 & 0 & 0 & 0 & 0 & 50 & 48 & 0 & 0 & 0 & 0 & 0 \\
\hline & 72 & 0 & 0 & 0 & 0 & 0 & 0 & & 72 & 0 & 0 & 0 & 0 & 0 \\
\hline & 96 & 0 & 0 & 0 & 0 & 0 & 0 & & 96 & 0 & 0 & 0 & 0 & 0 \\
\hline \multicolumn{5}{|c|}{ Percentage of allergic reaction } & & & & $0.00 \%$ & & & & & & \\
\hline
\end{tabular}

$E$ erythema; $O$ oedema; $D$ different 
central parts of the implant, new capillary loops were visible (Fig. 7.7 and 7.8).

Numerous fibroblasts surrounded the vascular-connective bands growing between the capsule and the implant (Fig. 7.4 and 7.6). The implants introduced into the intramuscular area were surrounded with a connective capsule, well-separated from the structure of skeletal muscle. No visible change in the form of reactive inflammatory cells was observed in the muscle area (Fig. 7.4, 7.5, and 7.6). There were no apparent signs of muscle interstitial fibrosis (Fig. 8.1 and 8.2). The macroscopic examination of the muscles surrounding the implants and of the stomach, liver, and kidneys confirmed the correct structure of internal organs and the degree of their blood supply. Macroscopically evaluated appearance of gastric and small and large intestine mucosa was within normal limits.

\section{Discussion}

Constantly rising expectancy of life and progress in the implant technology causes continuous increase in number of implantations in human medicine. Thanks to advance in the field of microscopy, suture materials and microsurgical instruments microsurgical techniques have developed to make surgical interventions at the finest structures of organism possible. In case of vascular prostheses, autogenous vessels are still most widely used due to their biocompatibility; however, this procedure requires additional operation and there are situations in which usage of this kind of prostheses is not possible. Moreover, the number of autologous grafts for coronary artery disease and for peripheral artery disease is limited. Due to this fact, scientists from all around the world started looking for alternatives. The ideal implant material should integrate without complications with tissue of the patient and maintain close connection over the time. Clinical problems such as damage of tissue around the implants, loosening of the implants, pain, and surgical revisions could be avoided. Particularly materials that will have contact with blood must comply with certain requirements such as mechanical strength, biocompatibility, blood compatibility, and sterilizability. Moreover, the inner and outer surface of artificial blood vessel must have different properties: outer should be overgrown with connective tissue whereas inner should be covered with endothelial cells and not stimulate adhesion of blood cells and components [13]. The essential requirement for biomedical materials is biocompatibility, referred as the ability of a foreign material implanted in the body to exist in harmony with tissue without causing deleterious changes. Generally, studies provide various results due to the different methodologies, workflow, and sample preparations [9]. Nowadays the most common clinically used synthetic grafts in peripheral artery disease remain expanded polytetrafluoroethylene, Dacron, and polyurethane [14]. Because of the unsatisfactory patency rates of common clinically used synthetic grafts, risk of stasis and thrombosis and rigidity, the researchers focus mainly on new grafts as

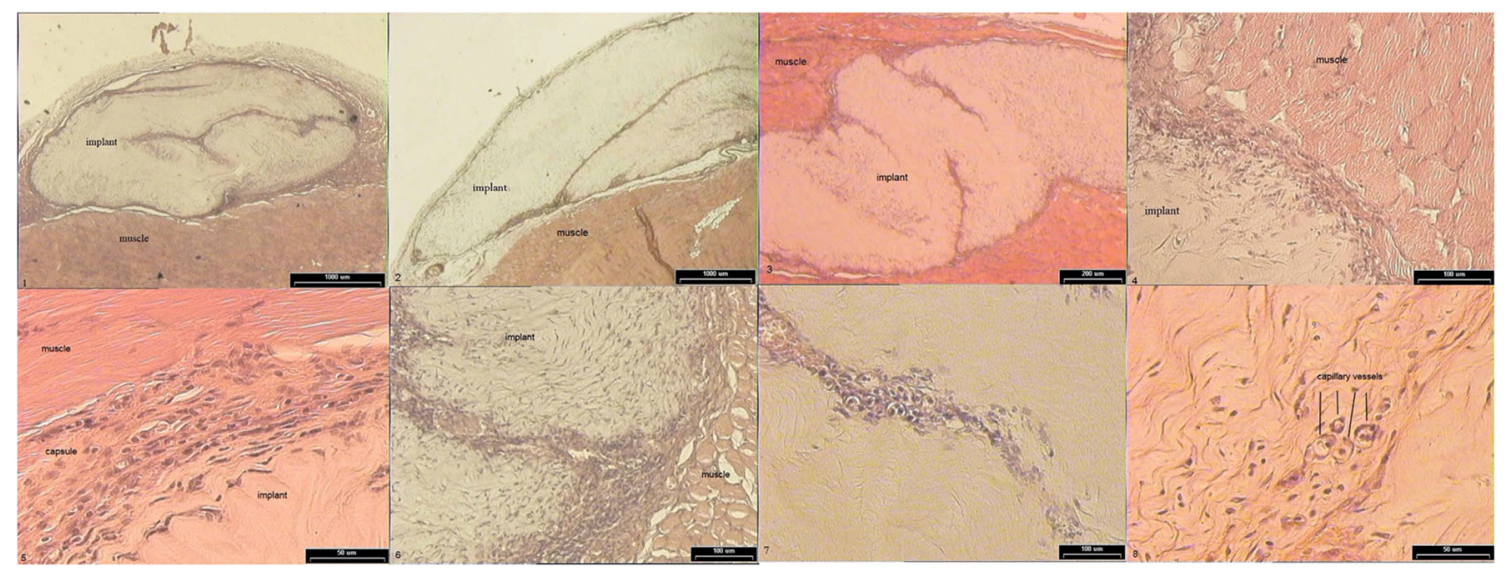

Fig. 7 Histopathological examination of BC tubes implants. (7.1) Shows the implant inserted underneath the epimysium, (7.2) implant on the muscle surface, and (7.3) implant inserted intramuscularly. The implants are surrounded by a thick connective tissue bag, from which vascular and connective tissue bands grow into the implant. (7.4) Intramuscular implant. The muscle is sharply separated from the implant by a bag made of connective tissue fibers, fibroblasts, and histiocytes. Numerous spindle cells (fibroblasts) and mononuclear cells penetrate from the capsule to the implant. The muscle has a normal structure without infiltration from the reagent cells. (7.5) Implant inserted underneath the epimysium. The muscle is separated from the implant by a bag made of connective tissue fibers, fibroblasts, and histiocytes.
Preparations stained with hematoxylin and eosin. Numerous spindle cells (fibroblasts) and mononuclear cells penetrate from the bag to the implant. The muscle has a normal structure without infiltration from the reagent cells. (7.6) Intramuscular implant. The muscle is sharply demarcated from the implant by a thick bag made up of connective tissue fibers, fibroblasts, and histiocytes. Strands of connective tissue with vessels grow into the implant. Numerous fibroblasts penetrate from the capsule and connective tissue band. (7.7) Intramuscular implant. The end of the connective tissue band in the center of the implant. Proliferating capillaries are visible. (7.8) Implant inserted intramuscularly. Visible groups of blood capillaries and numerous spindle cells (fibroblasts). No form of reactive inflammatory cells was observed in the muscle area 


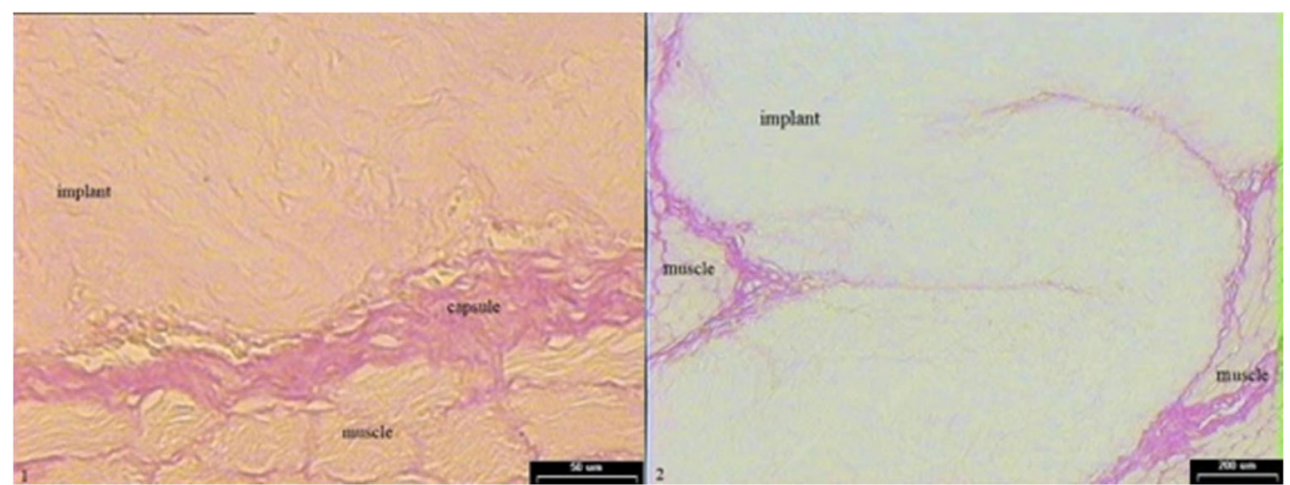

Fig. 8 Histopathological examination of implanted BC tubes. Preparations dyed Van Gieson. The implant inserted intramuscularly. The muscle is sharply demarcated from the implant by a bag made of collagen fibers and the implant inserted under the muscle. The muscle from the implant is sharply demarcated by a thick collagen fiber bag. A vascular and connective tissue band containing collagen fibers grows into the implant. No signs of muscle interstitial fibrosis

hypothesis about the lack of toxicity of materials based on nanocellulose and chitosan, we performed a number of tests, e.g., Toxicity Test No. 425: acute oral toxicity: up-and-down procedure; intradermal reactivity test; Guinea Pig Maximization Test No. 406: Skin Sensitization of Magnusson and Kligman (GPMT); and histopathological evaluation after implantation of vascular prosthesis of modified bacterial cellulose. Toxicity test showed that modified bacterial cellulose suspension does not exhibit any signs of pathology in animal behavior. Assessment of hair in the body's natural orifices, eye appearance, and muscle tension did not indicate any signs of toxic effects of the test substance. The autopsy confirmed a normal structure and blood supply to internal organs and orifices of the body. In Intradermal Reactivity Test, the non-polar and polar extract prepared from biological vascular prostheses of modified bacterial cellulose have been evaluated. None of the above showed an irritating effect. The maximization test (GPMT) No. 406: Skin Sensitization of Magnusson and Kligman confirmed lack of sensitization effect. During implantation process, correct structure of internal organs as well as the level of their blood supply was reported. Macroscopic view of gastric and small and big bowel was within normal limits. Histopathology assessment showed that in all animals, the implants were surrounded by a connective capsule mainly consisting of histiocytes, fibroblasts, and collagen fibers. In the muscle area, the reactive inflammatory cells were not found. There were no apparent signs of muscle interstitial fibrosis. Summarizing all obtained results, we can conclude that the study confirmed that biological vascular prosthesis of modified bacterial cellulose does not induce inflammatory response and hyperplasia of muscle tissue surrounding the implant. Previous studies on bacterial synthesized cellulose (BASYC®) have been a great success in the field of implantation and long-term maintenance of carotid arteries among rats and pigs. Another study conducted on BASYC® tube prosthesis for blood vessels has shown that $\mathrm{BC}$ has a potential to be used as a scaffold in tissue 
engineering process and in in vivo tissue-engineered blood vessels as part of cardiovascular surgeries. This work confirms that it will be possible to fabricate $\mathrm{BC}$ as in vitro scaffold and implant it as a substitute for a small diameter carotid arteries [17]. Wippermann et al. showed that BC exhibits properties that are promising for its further use in tissue-engineered blood vessels programs. Tissue-engineered blood vessels (TEBVs) represent an innovative approach for overcoming reconstructive problems associated with vascular diseases by providing small-caliber vascular grafts. Moreover they confirm that $\mathrm{BC}$ has high mechanical strength, promotes in situ vascular tissue regeneration, can be shaped into threedimensional structures, and does not require pre-treatment in the form of cell seeding. The new BC-engineering technique they used resulted in a production of new stable vascular conduits [7]. Scherner et al. investigated the biocompatibility, blood compatibility, and biostability of a novel biomaterial of bacterially synthesized cellulose (BC) as a potential scaffold for small-diameter TEBV. BC tubes were implanted to replace the carotid arteries of 10 sheep for a period of 3 months. Analysis of $\mathrm{BC}$ grafts in a sheep model revealed the development of a three-layered structure of these grafts similar to those of native arteries with a single layer of endothelium with basement membrane followed by a concentric layer of smooth muscle cells and an outer layer with adjacent tissue with ingrowing capillaries after 3 months. The study confirmed that BC grafts support the physical load imposed by hemodynamic environment and allow remodeling, have minimal inflammatory potential, and are functionally stable. All patent grafts displayed confluent luminal endothelialization without neointima or thrombus formation. Scherner et al. came to similar conclusions during the research on in vivo application of tissue-engineered blood vessels of bacterial cellulose. Conducted study confirmed that $\mathrm{BC}$ can be a potential scaffold for small-diameter TEBVs and confirmed the statement that in future, TEBV programs will be used for cardiovascular surgeries [8]. Leitão et al. demonstrated that grafts made of $\mathrm{BC}$ which was histologically evaluated do not show any signs of chronic inflammation, infection, foreign body responses, clot formation, cell in growth, and diameter via electron microscopy [18]. BASYC® a novel biomaterial introduced to the market by Lee et al. actually is successfully used for implantation and long-term maintenance of carotid arteries. Moreover BASYC® prostheses are non-toxic and have non-immunoreactive effect of BC implantation. Azevedo et al. obtained similar results to ours; he proved that cellulose and chitosan (CELL:CHIT) polymers are biocompatible, nontoxic, and very abundant, which make them good candidates for biomedical applications [19]. Kim et al. investigated the immunoreactivity of $\mathrm{BC}$ in vitro in human umbilical vein endothelial cells (HUVECs) and in vivo using $\mathrm{BALB} / \mathrm{c}$ mice. $\mathrm{BC}$ does not induce apoptosis and necrosis in HUVECs and does not stimulate immune response in both
HUVECs and BALB/c mice models. These results suggest that $\mathrm{BC}$ may be widely used as a biocompatible biomaterial for tissue engineering.

\section{Conclusions}

Biological vascular prosthesis of modified bacterial cellulose does not induce inflammatory response and hyperplasia of muscle tissue surrounding the implant. The tested substances do not cause any allergic, intradermal reactions and finally, do not display acute toxicity.

Acknowledgements The authors wish to thank Prof Jan Stetkiewicz for the pathological assessment of tissues and assistance when preparing relevant tables and figures.

Availability of Data and Material The datasets generated during and/or analyzed during the current study are available from the corresponding author on reasonable request

Author's Contribution JPZ: study design, interpretation of data, writing of the manuscript

$\mathrm{PZ}, \mathrm{KG}$, and JM: writing of the manuscript, analyzing and interpretation of data

JPZ, JS, and JW: acquisition of data

DC and RD: critical review of the manuscript

All authors acknowledge that they have read the Criteria for Authorship and have read and approved the final version of the manuscript submitted.

Funding The work was supported by Development of Biological Vascular Prostheses of Modified Bacterial Cellulose Research Project grant (no. N205 068 31/3102); patent PL 190961 "Method of obtaining modified bacterial cellulose."

\section{Declarations}

Ethics Approval The ethics governing the use and conduct of experiments on animals were strictly observed, and the experimental protocol was approved by the Nofer Institute for Occupational Medicine committee on Research ethics. The present study was conducted in accordance with the prior consent of the No. 9 Local Ethics Committee for animal experiments in Lodz and the Ethics Committee of the Medical University of Lodz, Poland; Resolution No. 49/LB 483/2009 on September 21, 2009.

Conflict of Interests The authors declare no competing interests.

Open Access This article is licensed under a Creative Commons Attribution 4.0 International License, which permits use, sharing, adaptation, distribution and reproduction in any medium or format, as long as you give appropriate credit to the original author(s) and the source, provide a link to the Creative Commons licence, and indicate if changes were made. The images or other third party material in this article are included in the article's Creative Commons licence, unless indicated otherwise in a credit line to the material. If material is not included in the article's Creative Commons licence and your intended use is not permitted by statutory regulation or exceeds the permitted use, you will need to obtain 
permission directly from the copyright holder. To view a copy of this licence, visit http://creativecommons.org/licenses/by/4.0/.

\section{References}

1. de Oliveira Barud HG, da Silva RR, da Silva BH, Tercjak A, Gutierrez J, Lustri WR, et al. A multipurpose natural and renewable polymer in medical applications: bacterial cellulose. Carbohydr Polym. Elsevier Ltd. 2016;153:406-20.

2. Lustri WR, Barud HG d O, Barud H d S, Peres MFS, Gutierrez J, Tercjak A, et al. Microbial cellulose - biosynthesis mechanisms and medical applications. In: Cellulose - Fundamental Aspects and Current Trends: InTech; 2015.

3. Torres F, Commeaux S, Troncoso O. Biocompatibility of bacterial cellulose based biomaterials. J Funct Biomater. 2012 Dec;3(4): 864-78.

4. Periayah MH, Halim AS, Saad AZM. Chitosan: a promising marine polysaccharide for biomedical research. Pharmacogn Rev. Medknow Publications. 2016;10:39-42.

5. Ciechańska D. Multifunctional bacterial cellulose/chitosan composite materials for medical applications. Fibres Text East Eur. 2004;12(4):69-72.

6. Lee SE, Park YS. The role of bacterial cellulose in artificial blood vessels. Molecul Cell Toxicol. Springer Verlag. 2017;13:257-61.

7. Wippermann J, Schumann D, Klemm D, Kosmehl H, Salehi-gelani S, Wahlers T. Preliminary results of small arterial substitute performed with a new cylindrical biomaterial composed of bacterial cellulose. Eur J Vasc Endovasc Surg [Internet]. 2009;37(5):592-6. Available from. https://doi.org/10.1016/j.ejvs.2009.01.007.

8. Scherner M, Reutter S, Klemm D, Sterner-Kock A, Guschlbauer M, Richter T, et al. In vivo application of tissue-engineered blood vessels of bacterial cellulose as small arterial substitutes: proof of concept? J Surg Res. 2014 Jun;189(2):340-7.

9. Lin N, Dufresne A. Nanocellulose in biomedicine: current status and future prospect. Eur Polym J. 2014;59:302-25.
10. Turbak AF, El-Kafrawy A, Snyder FW. AAB. Solv Syst Cellul. $1981 ; 4: 302,252$

11. Turbak AF. Newer cellulose solvent systems. In: Soltes EJ, editor. Wood and Agricultural Residues. New York: Academic Press; 1983. p. 87-99.

12. Magnusson B, Kligman AM. The identification of contact allergens by animal assay. The Guinea Pig Maximization Test. J Invest Dermatol [Internet]. 1968;52(3):268-76. Available from:. https:// doi.org/10.1038/jid.1969.42.

13. Klemm D, Schumann D, Udhardt U, Marsch S. Bacterial synthesized cellulose - artificial blood vessels for microsurgery. Prog Polym Sci [Internet]. 2001;26(9):1561-603 Available from: http:// www.sciencedirect.com/science/article/pii/S0079670001000211.

14. Weber C, Reinhardt S, Eghbalzadeh K, Wacker M, Guschlbauer M, Maul A, et al. Patency and in vivo compatibility of bacterial nanocellulose grafts as small-diameter vascular substitute. J Vasc Surg. 2018;68(6S):177S-187S.e1.

15. Hong F, Wei B, Chen L. Preliminary study on biosynthesis of bacterial nanocellulose tubes in a novel double-silicone-tube bioreactor for potential vascular prosthesis. Biomed Res Int. 2015;2015: $1-9$.

16. Aljebory A. Chitosan nanoparticles: review article Article in. Imp J Interdiscip Res. 2017.

17. Schumann DA, Wippermann ÆJ, Klemm ÆDO. Salehi-gelani TWÆS. Artificial vascular implants from bacterial cellulose: preliminary results of small arterial substitutes; 2009. p. 877-85.

18. Leitão AF, Faria MA, Faustino AMR, Moreira R, Mela P, Loureiro $\mathrm{L}$, et al. A novel small-caliber bacterial cellulose vascular prosthesis: production, characterization, and preliminary in vivo testing. Macromol Biosci. 2016;16(1):139-50.

19. Azevedo EP, Retarekar R, Raghavan ML, Kumar V. Mechanical properties of cellulose: chitosan blends for potential use as a coronary artery bypass graft. J Biomater Sci Polym Ed. 2013;24(3): 239-52.

Publisher's Note Springer Nature remains neutral with regard to jurisdictional claims in published maps and institutional affiliations. 